MEDICINE AND THE LAW

\title{
Interference with the clinical independence of doctors in hospitals faced with a shortage of resources: What should doctors do?
}

\author{
D J McQuoid-Mason
}

David McQuoid-Mason is Professor of Law at the Centre for Socio-Legal Studies, University of KwaZulu-Natal, Durban, South Africa, and publishes and teaches in medical law.

Corresponding author: D J McQuoid-Mason(mcquoidm@ukzn.ac.za)

In the face of interference with their clinical independence in hospitals with a shortage of resources, what should doctors do? The question can be answered by considering: ( $i$ ) the constitutional right to healthcare and emergency treatment; (ii) the common-law position regarding unlawful homicide and the doctrine of 'superior orders'; (iii) the ethical rules of the Health Professions Council of South Africa; and (iv) whether there is any protection for doctors who refuse to carry out unprofessional, unethical or unlawful directives from their superiors. While this article focuses on the public sector, some of the legal principles, where relevant, apply equally to doctors in the private sector.

S Afr Med J 2014;104(11):741-742. DOI:10.7196/SAMJ.8868

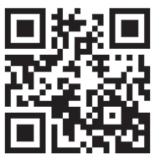

\section{Constitutional right of access} to healthcare and emergency medical treatment

The South African (SA) Constitution ${ }^{[1]}$ provides that everyone has the right of access to healthcare services within available resources (section 27(1)) and that nobody may be unfairly discriminated against (section 9(3)). It also provides that ' $[\mathrm{n}] \mathrm{o}$ one may be refused emergency medical treatment', which is not defined (section 27(3)). The National Health Act ${ }^{[2]}$ similarly mentions that '[a] health care provider, health worker or health establishment may not refuse a person emergency medical treatment', but also does not define what this means (section 5). The Constitutional Court, however, has defined 'emergency medical treatment' as treatment required for 'a dramatic, sudden situation or event which is of a passing nature in terms of time' (which means that it may be cured), and not a chronic terminal illness. ${ }^{[3]}$ One of the reasons for this is that doctors are expected not to engage in futile treatment ${ }^{[4]}$ and waste valuable resources - particularly in the resource-constrained public hospitals of SA. In the case of public officials and institutions, the Public Finance Management Act ${ }^{[5]}$ provides that accounting authorities are required to 'prevent irregular expenditure, fruitless and wasteful expenditure ... and expenditure not complying with the operational policies' of the public entity (section 51).

The common-law position regarding unlawful homicide and the doctrine of 'superior orders'

The common law states that a doctor who intentionally or negligently and unlawfully causes the death of another - whether by an act or an omission - may be criminally and civilly liable for homicide. In the case of an intentional unlawful act or omission causing death, the perpetrator may be guilty of the crime of murder ${ }^{[6]}$ and civilly liable for a dependant's action if the deceased person was supporting lawfully recognised dependants. In the case of a negligent act or omission causing death, the perpetrator may be guilty of the crime of culpable homicide ${ }^{[7]}$ and liable to a dependant's action. ${ }^{[8]}$ The question of what is unlawful depends on the legal convictions or boni mores of society, which in a constitutional democracy such as SA is influenced by the values in the Constitution. ${ }^{[9]}$ Hence an intentional or negligent breach of a person's constitutional rights may well be evidence of an unlawful act or omission.

The common law also states that 'superior orders' are not a defence to an unlawful act or omission where the person carrying out the order knew, or ought to have known, that what they were doing was unlawful. ${ }^{[10]}$ Doctors cannot raise the defence that their employer or superior directed them to engage in conduct that was unprofessional, unethical or illegal - unless their act, or failure to act, was under duress (e.g. they were forced to act unlawfully in order to prevent greater harm to themselves or their immediate family). ${ }^{[1]}$

\section{Vicarious liability}

In order for employers such as provincial authorities or hospitals to be vicariously liable for the wrongful conduct of their employees, the persons suing them must show that the employees had committed an unlawful act or omission while acting in the course and scope of their employment - even if the work was carried out in an improper way. ${ }^{[12]}$ Consequently, hospitals will be liable if their employees intentionally disobey hospital protocols or standard operating procedures where such acts or omissions fall within the course and scope of the employees' employment. Although a provincial authority or a hospital is vicariously liable for the conduct of its employees, the employees themselves may be held personally liable. ${ }^{[13]}$ Employees may therefore be personally sued, or, depending on their employment contract, may be liable to reimburse their employers for any damages paid out to injured or harmed patients. According to the State Liability Act, ${ }^{[14]}$ the state is vicariously liable for the delictual acts or omissions of state employees on the same basis as other employers (section 1). ${ }^{[15]}$

\section{The ethical rules of the medical profession}

The ethical rules of the Health Professions Council of South Africa (HPCSA $)^{[16]}$ require doctors not to permit themselves 'to be exploited in any manner' (rule 22), to 'act in the best interests' of their patients 
at all times (rule $27 \mathrm{~A}(\mathrm{a})$ ), and to 'maintain the highest standards of personal conduct and integrity' (rule 27A(c)). Doctors who allow themselves to ignore these ethical rules of their profession, under pressure from their superiors, are therefore clearly acting unprofessionally and unethically. Not only may such doctors be sanctioned by the HPCSA for unethical behaviour, but their conduct may also result in criminal or civil liability. In addition, the HPCSA rules require doctors to report any unprofessional, unethical or illegal conduct by colleagues (rule 25(1)(c)).

The World Medical Association Declaration of Seoul on Professional Autonomy and Clinical Independence ${ }^{[17]}$ states that 'professional autonomy [i]s an essential component of high quality medical care' and 'maintaining and assuring the continuation of professional autonomy in the care of patients ... is an essential principle of medical ethics. This principle is fundamentally undermined if the professional autonomy of doctors is interfered with.

\section{Protection of doctors who refuse to carry out unprofessional, unethical or unlawful directives from their superiors}

Doctors who refuse to carry out unprofessional, unethical or illegal directives from their superiors, or anyone else, may not be victimised for their actions. The Constitution provides that everyone is entitled to fair labour practices (section 23(1)), and this is enshrined in the Labour Relations Act. ${ }^{[18]}$ The Act regulates the relationship between employers and employees and protects the rights of employees against potential abuse by employers. An employee who is disciplined, discriminated against or dismissed for failing to carry out an unprofessional, unethical or unlawful directive from a superior would clearly have an action for an unfair labour practice (chapter VIII). By obeying such a directive, the employee risks being disciplined by his/her professional body and held criminally or civilly liable, and moreover cannot raise the defence of having acted under 'superior orders. ${ }^{[9]}$

Likewise, a doctor who carries out the HPCSA ethical duty to report unprofessional, unethical or unlawful conduct by a fellow practitioner $^{[16]}$ - even if he or she is a 'superior' such as an MEC for health, a provincial head of health, a hospital manager, or any other person in authority, who is registered with the HPCSA - will be protected by the common-law principle of 'qualified privilege'. A qualified privilege exists where the person making disclosure has a moral, legal or social duty to make the disclosure to a person who has a reciprocal interest in receiving the information, ${ }^{[19]}$ provided this is in circumstances not actuated by malice.
Doctors who report unprofessional, unethical or unlawful conduct by fellow practitioners may also be protected by the Protected Disclosures Act, ${ }^{[20]}$ which is designed to protect whistle-blowers in both the public and private sectors. The Act protects whistle-blowers from disciplinary action, dismissal, suspension, demotion, harassment, intimidation, transferral against their will, refusal of transfer or promotion, or any other form of victimisation that affects their employment, profession, office, employment opportunities or work security. In terms of the Act, such disclosures to a specified person or body such as the Public Protector or Auditor-General (section 8), or as a 'general protected disclosure' (section 9), will be protected. In the latter situation, a report to the HPCSA in terms of its ethical rules would clearly be a 'protected disclosure' provided the communication is made in good faith, is believed to be substantially true, and is not made for personal gain (section 9(1)). Whistle-blowers are also protected by the Labour Relations Act, ${ }^{[18]}$ which states that a person who is dismissed for reporting abuse in terms of the Protected Disclosures Act ${ }^{[20]}$ will have an action for unfair dismissal (chapter VIII).

\section{Conclusion}

Doctors who allow their legal and ethical obligations to patients to be subverted risk being subjected to criminal and civil sanctions, as well to disciplinary action by the HPCSA, and cannot raise the defence of 'superior orders'.

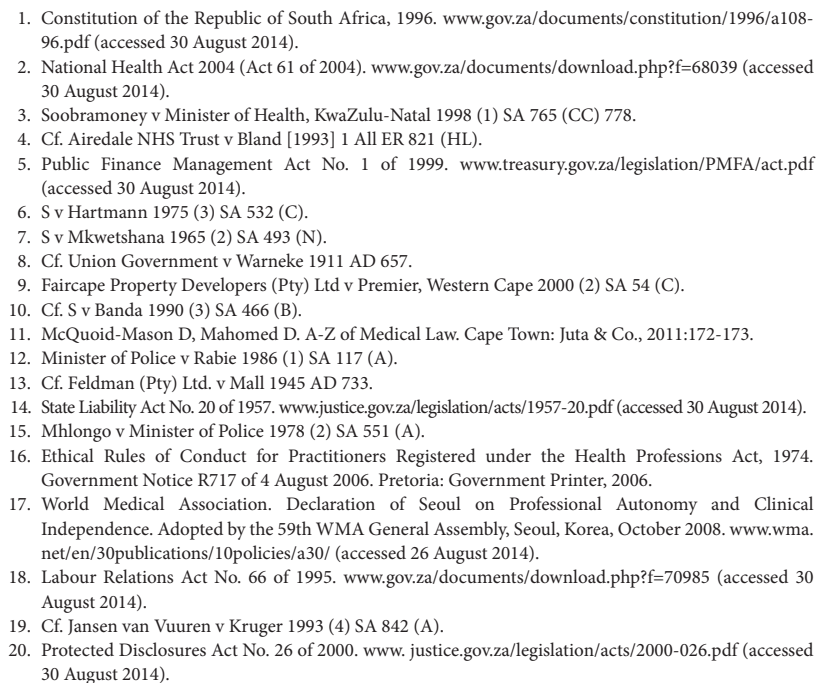

Accepted 28 August 2014. 